\title{
Assessing Ict Role to Economic Convergence of Albania and Western Balkans to European
}

\author{
Ermelinda Xhaja (Gjika) \\ PhD Candidate, Faculty of Economy, University of Tirana
}

Ermelinda Kordha (Tolica)

Prof. Asc. Faculty of Economy, University of Tirana

\begin{abstract}
The Western Balkans countries are still considered economies in transition. Coming from centralized systems with low level of GDP per capita the region can accelerate substantially the growth pace as lectured in neoclassical growth theory. The region is considered attractive for foreign investments due to a series of advantages such as the political EU agenda and vicinity to EU markets, low labour costs combined with relatively well educated people. The growth models recognize the importance of technology factor to sustain the productivity, competitiveness and economic growth. Promoting innovative businesses and introducing information and communication technologies (ICTs) will enhance the potentials for economic convergence towards developed economies such as EU. The aim of this paper is to bring in focus the impact of ICT on productivity in the Western Balkans (WB) as well as to the structural convergence within the region. One of the contributors for introduction of new technologies and use of ICT remains the foreign direct investments. The paper will assess the role of FDls in modelling aggregate production reflected through the exports variety and in particular ICT and high technology goods exports. The methodology of the paper makes use of time series data for a set of indicators for each of the Western Balkans countries: Albania, Bosnia and Herzegovina, Kosovo, Macedonia, Montenegro and Serbia. The main conclusion is that the Western Balkans and Albania have shown a slight trend of convergence of productivity among them and to EU by still is not following the same pace as the convergence of GDP per capita. The impact of ICT development in Albania at firm level but also at economic growth is lower than in other Western Balkans countries. The penetration of FDIs in Albania has generated limited contribution to the introduction of new technologies and sophistication of business models. Additionally, it is necessary to address some incentives to promote ICT businesses and professional skills in order to enable the innovation and competitiveness of Albanian economy.
\end{abstract}

JEL classification: F15, F43, 016, 047.

Keywords: Economic convergence, economic growth, technology, innovation, foreign direct investments, economic integration.

\section{Introduction}

The Western Balkans (WB) countries ${ }^{1}$, Albania, Bosnia and Herzegovina, Macedonia, Montenegro and Serbia, are moderately recovering from the hit of the global economic crisis with an average economic growth rate, estimated for 2015 in the last World Bank report at average 2.1\%, still far from the pre-crises rates. The decline of growth rate has increased the convergence gap between the region and the European Union (EU) where the countries are aspiring to be members. GDP per capita in PPP of the region is almost the half of the EU countries. Although the countries have tried to converge at some degree among them and with $\mathrm{EU}$, the pace of convergence is decreasing and there is need for other stimulus in

\footnotetext{
${ }_{1}^{1}$ Data for Kosovo were missing for some of the variables, thus Kosovo is excluded from the analyses.
} 
the economies of the region to boost growth (Meksi, Xhaja, 2015). The region has seen considerable FDls' inflows for the early 2000s, but the flow has not been steady in the recent years due to the crises in the countries of origins. The region counts a number of advantages in geographical, political and economical terms but still needs to find ways to stimulate growth through attraction of productive investments making best use of its comparative advantages. An important element is the promotion of innovation and technology to the economy.

The aim of this paper is to look into the role of ICT on productivity of WB economies as one of the key elements that may encourage convergence toward EU. Herein, it will be analyzed if introduction of ICT in the economy through two indicators, ICT imports and ICT exports, has contributed to productivity growth. In particular, it will be seen if there is any impact by FDIs on the attraction of new technologies and development of ICT sector. The variables engaged in this paper are GDP per person employed, FDI inflow as percentage of GDP, ICT goods imports and exports. The timeframe in study is 2006 2014 where the data are available for all countries in the paper. The data are generated by the World Development Indicators Database. The ICT contribution to economy, through imports and exports remain modest in all Balkan countries, but there is a difference on the impact of FDIs on productivity implying the differences in the attraction of technology on manufacturing goods. The improvements on ICT contribution have two-aspects: the ICT sector itself as well as the application of innovation and technologies in other sectors such manufacturing and services.

\section{Literature review}

One of the most important models of economic growth is the Solow model (1956). According to the third derivation of this model of diminishing returns, within the economies with same important features, the revenues will tend to converge, from the the less developed economy to the developed ones. The convergence model gives insights to the developing countries by implying that, if they can fulfil some preconditions in terms of political and economic stability, good governance, business climate, they can accelerate their development process and converge to the developed countries or steady state (Meksi, Xhaja 2014). The neoclassical economists of the 1950s and 1960s recognized the importance of technology in the basic growth model for enabling the economy to grow in per capita in the long run.

The convergence hypothesis would be supported by the "advantages of backwardness"-literature, in particular Gerschenkron (1962) and Abramovitz (1986). In this light, CEE countries would benefit from the combination of rapid technology (ICT) diffusion and major restructuring of (in particular) the manufacturing sector. According to the study of van Ark and Piatkowski, 2004, in particular when increased investment took place in new types of capital, such as ICT capital, it may have been a major source of accelerated productivity growth. An important issue, however, is to what extent ICT capital directly contributes to labor productivity growth, and to what extent it works through total factor productivity growth by industries that either produce or use ICT capital intensity intensively. Indeed during the 1990s, ICT capital has been a more important source of growth in the "old" EU countries during the 1990s than ICT-related TFP growth (Jorgenson 2004, Colecchia and Schreyer, 2001, Daveri, 2002, and van Ark, Timmer and Ypma 2003).

This issue is all the more important from the perspective of catch-up growth. Krugman (1994) and Young (1995) indicated that most of growth in the Asian was driven by increases in capital intensity rather than by TFP growth. Unfortunately, detailed work on the role of ICT, using growth accounting techniques, for new and non-OECD countries is still limited, but the evidence available so far suggests an impact from ICT capital although there is much variation (Lee and Kahtri, 2003).

Piatkowski (2002) directly focuses on ICT investment from the viewpoint of the economic and institutional determinants. He constructs a "New Economy Indicator", which tries to measure the capability of 27 transition economies to exploit the potential of ICT to accelerate the long-term economic growth and catching-up with developed countries. According to Prof. Abramovitx, (1950), the second way for increasing output in the economy is to use new ways for getting more output from the same number of inputs. Only about $15 \%$ of the actual growth in the output of the American economy was due to the measured growth of inputs (i.e., in capital and labor) for an 80 year period. The rest of $85 \%$ was an unexplained residual even in many other studies, including Robert Solow studies in the 1960. The size of this residual persuaded most economists that technological innovation must have been a major force in the growth of output in highly industrialized economies. The impact of a technological innovation will generally depend not only on its inventors, but also on the creativity of the eventual users of the new technology. 


\section{Convergence of productivity and the impact of innovation}

Throughout this paper, we refer to only one variable, the GDP per person employed to evaluate the productivity. Data about GDP per person employed are generated by the World Development Indicators Database for all the countries in study. The WB region has seen an increase of the productivity during the transition path at 6 points per GDP per capita and at 5 points at GDP per employee; although the proportions toward EU for 2005 have been different for both indicators. However, in the catching up stage, the productivity still remains at less than half of the EU for most of the WB countries (see Figure 1).

\section{Figure 1. Share of GDP per person employed toward EU}

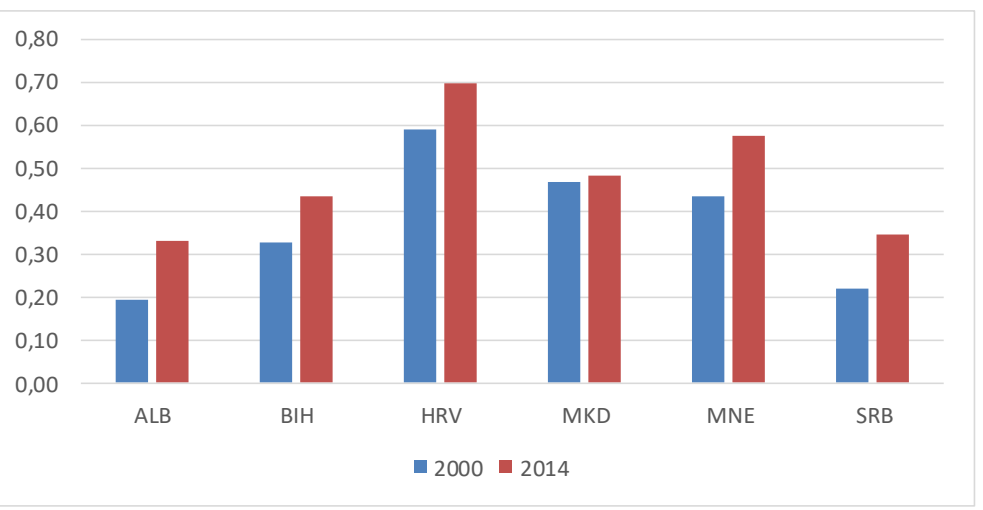

Source: World Development Indicators

Meksi, Xhaja (2015) have calculated the speed of convergence through $\beta$ for the GDP per capita in PPP per WB countries toward EU. The parameter $\beta$ gives information on the speed of convergence or what distance from the steady state is covered annually.

Based on the same model is estimated the convergence of productivity through the regression equation of independent variable log GDP per employee 2005 and depended variable, the growth rate of GDP per employee per 2005-2014. If there is evidence of negative correlation and the conditions for the regression analyses are satisfied then, it may be concluded that, there is an absolute convergence among the productivity levels of the WB countries.

\section{Figure 2: Scatter plot of the productivity convergence of WB to EU}

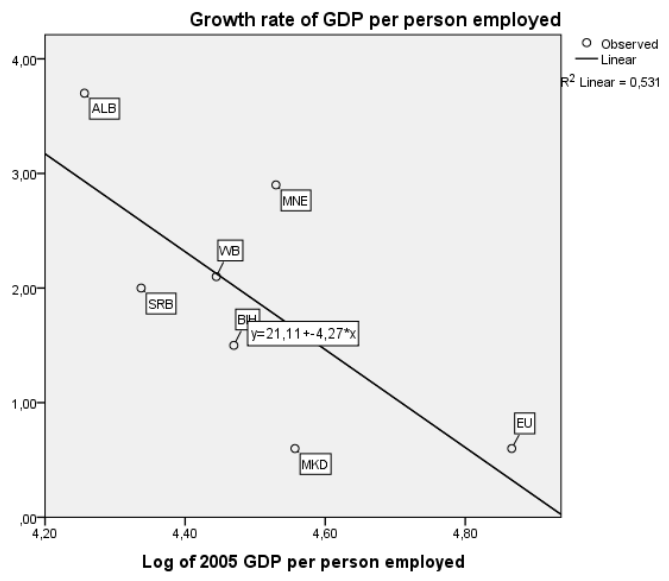

Authors' calculations. Source of data: World Development Indicators 
The Figure 2 shows the scatter plot of the regression for the convergence of productivity of the WB countries toward EU. Whereas, the regression results have confirmed a moderate correlation among the two variables. The $\beta$ convergence indicator is calculated at $4 \%$, based on these results. So, although there is a tendency of convergence of productivity, it is not following the same pace as the convergence of GDP per capita concluded in Meksi, Xhaja (2015) at 5,2\% speed rate.

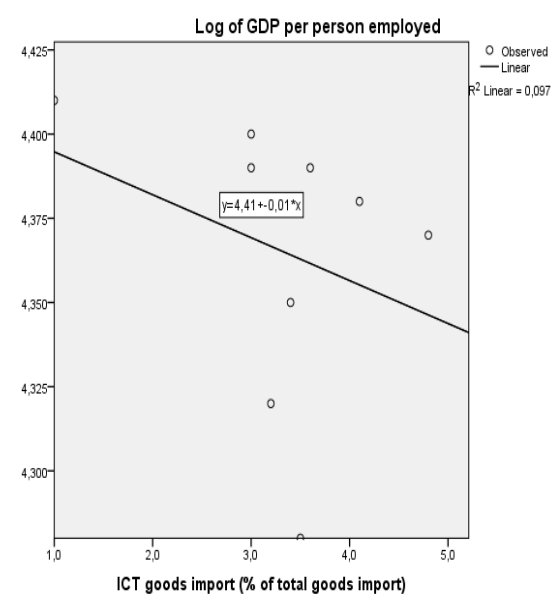

Figure 3: Scatter plot of the ICT imported goods to productivity for Albania

Authors' calculation. Source of data: World Development Indicators

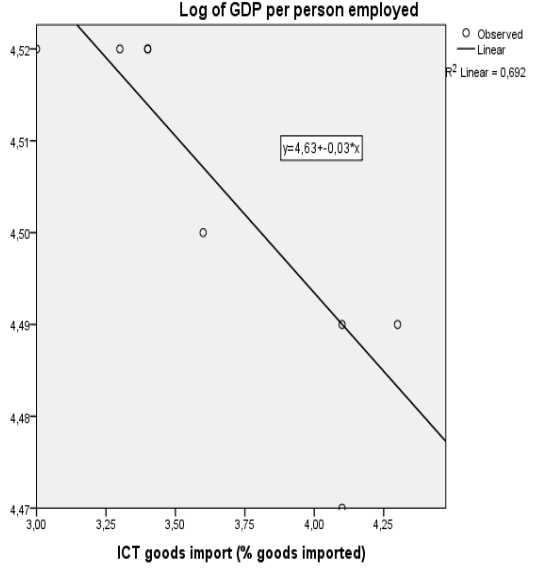

Figure 4: Scatter plot of the ICT imported goods to productivity for Western Balkans

How can the region boost productivity and growth and be more competitive to the European markets? One of the key factors for competitiveness and productivity is the boosting of innovation in economy. Based on the Global Competitiveness Indicators of World Economic Forum the WB is lagging behind the developed economies and in particular the EU on the innovation pillar. For 2015-2016 report, the region is ranked in the $105^{\text {th }}$ position for business sophistication and the $95^{\text {th }}$ for innovation while the EU respective rankings are 39th and 37th position.

In order to measure any impact of the innovation for the Western Balkans economies a proxy indicator of ICT imported goods is used. A regression analyses of ICT and GDP per person employed is conducted to investigate any correlation among variables. The results are shown in the Figure 3 for Albania and Figure 4 for other Western Balkans countries. The regression results demonstrate a significance of the impact for the Western Balkans where also the correlation is stronger, while such relationship is not testified for Albania where the regression is not significant as well as the correlation value. The growth exogenous model poses the question if an economy may enjoy positive growth rates by simply saving and investing? What kind of investments are need in the economy to boost growth through productivity?

The foreign direct investments (FDI) can be a promoter of the new technologies and innovation of the economy. Based on data from the Bank of Albania (BoA), the FDI stock in Albania is concentrated mainly in: transportation and communication at about $27 \%$ of the total, financial services at around $17 \%$, and the extractive industry for about $15 \%$.

Meanwhile, in the region, the overview of distribution of FDIs by sector appears different. Thus, the main FDI sectors in Serbia are the financial sector and the manufacturing industry, such as automotive, electric, food and textile industries; FDls in recent years in Macedonia have been focused on the automotive industry; the industry, banks and telecommunications are the sectors with the highest inflow in Bosnia and Herzegovina; tourism is the dominant sector in Montenegro. A good part of the FDI inflow in the region is dedicated to the privatization of state assets, which are now exhausted as opportunities for attracting foreign investments. 
The relation between FDIs inflows and ICT imported goods (\% of total import goods) for the period 2006 -2014 is considered in the analyses with the purpose of understanding if the FDI-s inflow has contributed to the new technologies and innovation. The ICT imported goods is used as proxy variable for indicating the level of innovation in the economy. A regression analysis has been conducted between two variables as shown in the scatter plot below, Figure 5 . The dependent variable is the ICT imported goods to understand if the FDIs have been oriented toward attraction of new technologies or have mainly remained on intensive labour and natural resources. The same regression analysis is made separately for Albania and the WB where the variables are calculated as average of the WB countries indicators.

Figure 5 The scatter plot of the regression for Albania of the ICT imported goods and FDls inflow

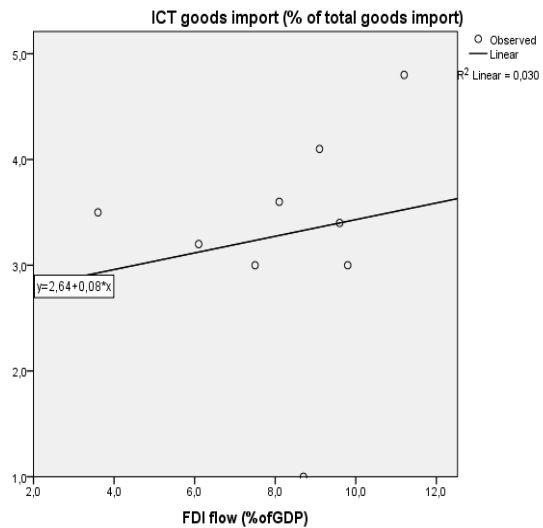

Figure 6. The regression scatter plot for the WB among ICT imported goods and FDIs inflow

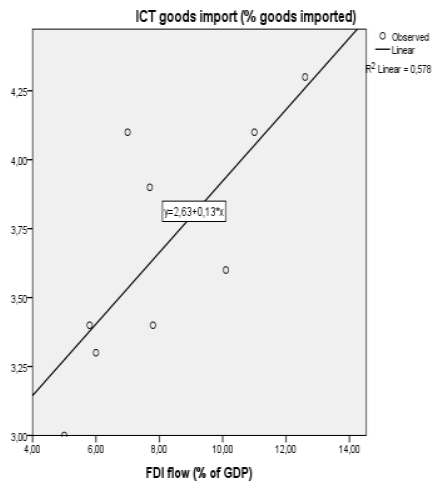

\section{Authors' calculations. Source: World Development Indicators}

Apparently, the results of the regression for Albania compared to Western Balkans differ as seen in the respective scatterplots as well as in the coefficients errors and significance. The analyses don't support any correlation in Albania where apparently the FDls are not oriented toward innovative and sophisticated business models. Meanwhile, the regression results for the Western Balkans are more pertinent showing a degree of correlation and significance of such impact in the contribution of FDIs in the ICT contribution to the economies.

According to the World Bank data the ICT imports as a share of total goods imports remain at very low level compared with $\mathrm{EU}$ and for some countries like Albania the flow is not steady, even in decline (see Figure 7).

Figure 7: ICT good imports (as \% of total goods imports) WB countries and EU

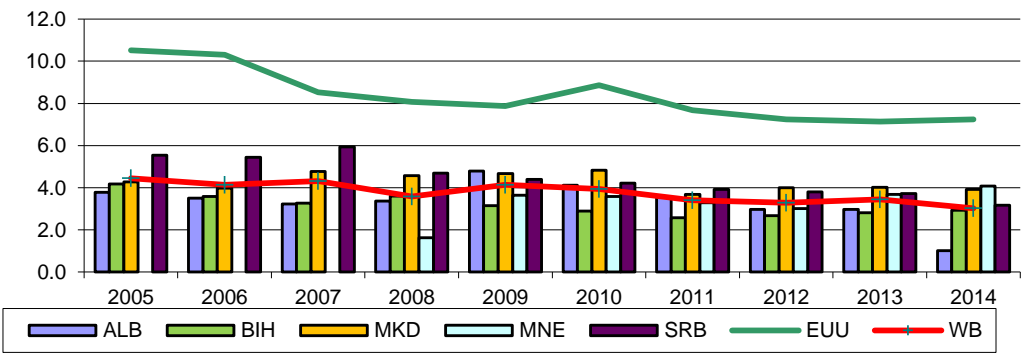

Source: World Development Indicators 
The picture differs within the countries of the WB region referring to the willingness of firms to be innovative using technology, (see Table 1). Albanian firms are reaching in some indicators the average for Eastern Europe and Central Asia, but they are still among the last performers in the region. More efforts at firm level on innovation and sophistication will be reflected in the evolution of goods and services produced by the economy and their competitiveness in the international markets. The main Albanian exported goods are mainly oriented by labor intensive industries rather than capital intensive in sectors such as extractive industries and textiles. Additionally about $99 \%$ of the companies are small and medium enterprises with less than 250 employees.

\section{Table 2. Innovation at firm level according to BEEPS V}

\begin{tabular}{|c|c|c|c|c|c|c|c|}
\hline $\begin{array}{l}\text { Indicators for Innovation and } \\
\text { Technology }\end{array}$ & Albania & $\begin{array}{l}\text { Bosnia\& } \\
\text { Hercegovina }\end{array}$ & Croatia & Macedonia & Montenegro & Serbia & $\begin{array}{l}\text { Eastern } \\
\text { Europe } \\
\text { and } \\
\text { Central } \\
\text { Asia }\end{array}$ \\
\hline $\begin{array}{l}\text { Percent of firms with an } \\
\text { internationally-recognized } \\
\text { quality certification }\end{array}$ & 18,8 & 32,2 & 24,1 & 34,8 & 13,8 & 32,5 & 23 \\
\hline $\begin{array}{l}\text { Percent of firms using } \\
\text { technology licensed from } \\
\text { foreign companies }\end{array}$ & 17,5 & 20,6 & 12,9 & 8,9 & 9,0 & 21,0 & 16,9 \\
\hline $\begin{array}{l}\text { Percent of firms having their } \\
\text { own Web site }\end{array}$ & 50,6 & 63,4 & 70,2 & 58,7 & 29,7 & 74,0 & 54,8 \\
\hline $\begin{array}{l}\text { Percent of firms using e-mail } \\
\text { to interact with } \\
\text { clients/suppliers }\end{array}$ & 51,5 & 96,0 & 95,3 & 87,9 & 81,7 & 96,8 & 79,8 \\
\hline $\begin{array}{l}\text { Percent of firms with an } \\
\text { annual financial statement } \\
\text { reviewed by external } \\
\text { auditors }\end{array}$ & 16,7 & 67,8 & 31,5 & 16,4 & 46,4 & 32,8 & 34,4 \\
\hline
\end{tabular}

Source: Enterprise Surveys 2013, the World Bank - EBRD

Looking to the ICT exports (\% of total goods exports) their value still remains very low in the region toward the total of exports, but if we consider the ICT service exports, the region is experiencing a more substantial contribution of this sector to the total of exports. the differences in the value toward ICT goods exported and ICT service exported can be seen in the Figure 8 and 9 below.

Figure 8. ICT goods exports (as percentage of exported goods)

Figure 9. ICT service exports (as percentage of service exports)
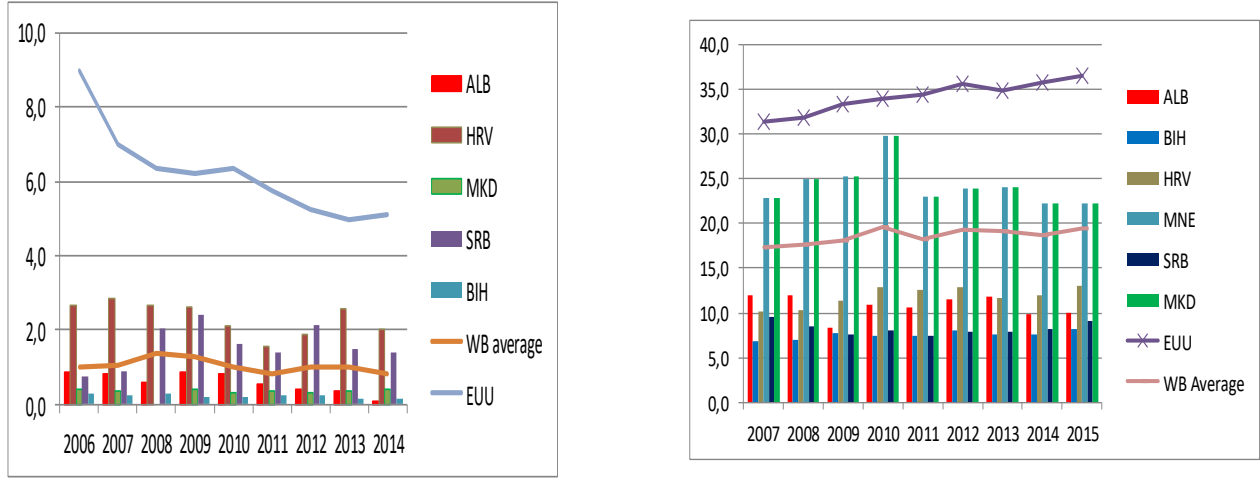

Source: World Development Indicators 
In the recent years, particularly the activities of business outsourcing services such as in marketing, IT, accounting, data processing, etc. are more present in all the region, attracted by the low labor cost, good knowledge of foreign languages as well as young and educated work force. Although, they serve mainly foreign markets in EU and US and there are still potentials for further specializing in particular in IT services and programming in the region. A good policy in motivating the skills in ICT is necessary in particular in Albania where there are still notable gaps between labor market needs in the sector and education.

\section{Conclusions}

Albania and other Western Balkans countries are committed toward the EU membership and the integration process requires also that countries catch the EU standards and be able to fairly compete in the European markets. The paper has concluded that the countries are moderately converging on terms of productivity, but still are far from making their economy more competitive to attract foreign investments and high technology investments. The difference is made more evident for Albania where there is not confirmed any impact of the FDIs on ICT development or the ICT contribution to the productivity. Thus, it confirms that Albania has an immediate need for policies and incentives to improve skills and business environment in attracting more human and physical capital intensive investments to transfer knowledge and skills based on its comparative advantages, resources and sectors and thus contribute to longer term growth.

\section{References}

[1] Ark, B. Van and M.P Timmer (2003), "Asia's Productivity Performance and Potential: The Contribution of Sectors and Structural Change", paper presented at RIETI-KEIO Conference on Japanese Economy: Leading East Asia in the 21st Century?, Tokyo, 30 May (downloadable from http://www.eco.rug.nl/medewerk/Ark/pdf/Asia Paper4.pdf)

[2] Ark, B.Van and M. Piatkowski (2004), "Productivity, Innovation and ICT in Old and New Europe" Research Memorandum GD-69

[3] Bank of Albania Data

[4] Business Environment and Enterprise Performance Survey V (BEEPS V), EBRD - World Bank

[5] Colecchia, A. and P. Schreyer (2001), "ICT Investment and Economic Growth in the 1990s: Is the United States a Unique Case? A Comparative Study of Nine OECD Countries", STI Working Paper 2001/7, $\mathrm{OECD}$, Paris.

[6] Daveri, F. (2002), "The New Economy in Europe, 1992-2001", Oxford Review of Economic Policy, vol. 18(3), pp. 345-362.

[7] Global Competitiveness Report 2015-2016 (downloadable from http://www3.weforum.org/docs/gcr/20152016/Global_Competitiveness_Report_2015-2016.pdf)

[8] Technical Note, "Incentive Policies for Investment Promotion: Albania Vs Western Balkans Countries", Albania Investment Council, April 2016 (downloadable from https://www.investment.com.al/wpcontent/uploads/2015/08/EN Technical-Note.pdf)

[9] Jorgenson, D.W. (2004), 'Information Technology and the G7 Economies', Harvard University, mimeographed (downloadable from http://post.economics.harvard.edu/faculty/jorgenson/papers/handbook.extract03152004.pdf)

[10] Lee, II Houng and Y. Kahtri, 'Information Technology and Productivity Growth in Asia', IMF

[11] Meksi E. and Ermelinda Xh. (2015) "On economic convergence of Albania and other Balkan countries with EU", International Journal of Science, Innovation and New Technology, Vol. 1, No. 13

[12] Sanfey, P., Jakov, M. and Ana, K. "How the Western Balkans can catch up", Working Paper No.186, EBRD (downloadable from http://www.ebrd.com/news/2016/how-the-western-balkans-can-catch-up.html)

[13] Working Paper, WP/03/15, 2003, Washington D.C.

[14] World Bank Group, South East Europe, Regular Economic Report, No.9 Spring 2016

[15] World Development Indicators 